\title{
MODEL PEMBELAJARAN KNISLEY UNTUK MENINGKATKAN KEMAMPUAN PEMAHAMAN KONSEPTUAL MATEMATIS SISWA SMP
}

\author{
Wieka Septiyana ${ }^{1}$, Arina N. Indriani ${ }^{2}$ \\ ${ }^{1}$ Universitas Pendidikan Indonesia \\ Wieka.septiyana@yahoo.com \\ ${ }^{2}$ Universitas Pendidikan Indonesia \\ arina.math@gmail.com
}

\begin{abstract}
ABSTRAK
Kemampuan pemahaman konseptual matematis (KPKM) siswa merupakan bekal dalam memecahkan masalah dan menemukan konsep lain. Oleh karena itu, penelitian ini perlu dilakukan untuk mengetahui model pembelajaran matematika yang dapat meningkatkan kemampuan tersebut. Tujuan utama penelitian ini untuk menyelidiki dan mendeskripsikan pencapaian serta peningkatan kemampuan pemahaman konseptual matematis siswa baik yang mendapat pembelajaran dengan model pembelajaran matematika Knisley maupun dengan model pembelajaran langsung. Metode penelitian yang digunakan adalah menggunakan metode campuran (mixed method) dengan model penggabungan kuantitatif dan kualitatif. Desain penelitian yang digunakan yaitu concurrent embedded design. Populasi dalam penelitian adalah siswa kelas VIII SMP dengan sampelnya 73 siswa kelas VIII. Sampel dipilih menggunakan teknik purposive sampling. Analisis data kuantitatif dalam penelitian ini dengan menggunakan Independent-Sampels T-test dan Mann-Whitney. Hasil analisis statistika deskriptif kelas eksperimen menunjukkan $\bar{x}_{\text {pretes }}=0.83, \bar{x}_{\text {postes }}=14,92$ dan $\overline{\boldsymbol{x}}_{N \text {-gain }}==0,58$. Dan kelas kontrol menunjukkan $\overline{\boldsymbol{x}}_{\text {pretes }}=0.89, \overline{\boldsymbol{x}}_{\text {postes }}=10,27$ dan $\overline{\boldsymbol{x}}_{N \text {-gain }}=0,39$. Berdasarkan hasil uji Independent-Sampels T-test untuk mengetahui pencapaian dan menguji skor $N$ gain KPKM siswa diperoleh masing-masing data dengan nilai sig (1-tailed) dan $\alpha=0,05$ yaitu 0,000. Karena nilai sig $0,000<0,05$ maka $H_{0}$ ditolak sehingga hipotesis diterima. Dengan demikian, hasil penelitian menyimpulkan bahwa pencapaian dan peningkatan kemampuan pemahaman konseptual matematis siswa yang mendapatkan pembelajaran model pembelajaran matematika Knisley lebih baik daripada siswa yang mendapatkan pembelajaran langsung.
\end{abstract}

Kata Kunci: Pemahaman Konseptual Matematis, Model Knisley, Mix Method.

\begin{abstract}
The conceptual understanding of mathematical ability is a provision in solving problems and finding other concepts. Therefore, this research should be conducted to determine the mathematical learning model that can enhance these capabilities. The main objective of this research to investigate and describe the achievement as well as an increase in the mathematical ability of conceptual understanding both got teaching Knisley mathematics learning model and direct learning model. The method used mixed method with combination of quantitative and qualitative models. The study uses concurrent embedded design. The population in this research is class VIII SMP with 73 students of
\end{abstract}


class VIII as samples. Samples were selected using purposive sampling technique. Quantitative data were analysed using Independent-Samples T-test and Mann-Whitney. Results of descriptive statistical analysis showed the experimental class $\bar{x}_{\text {pretes }}=0.83, \bar{x}_{\text {pastes }}=14.92$ and $\bar{x}_{\mathbb{N} \text {-gain }}=0.58$. And a control class shows $\bar{x}_{\text {pretes }}=0.89, \bar{x}_{\text {postes }}=10.27$ and $\overline{\boldsymbol{x}}_{\mathbb{N} \text {-gain }}=0.39$. Based on the test results of the samples Independent-T test to determine achievement and test scores N-gain KPKM each student obtained the data with sig (one-tailed) and $\alpha=0.05$ is 0.000 . Because sig $0.000<0.05$ then rejected that hypothesis is accepted. Thus, the research concludes that the attainment and improved conceptual understanding of mathematical ability of students who get teaching mathematics learning model Knisley better than students who received direct instruction.

Keywords: Mathematical Conceptual Understanding, Knisley Learning Model, Mix Method.

Format Sitasi: Septiyana, W. \& Indriani, A. N. (2018). Model Pembelajaran Knisley untuk Meningkatkan Kemampuan Pemahaman Konseptual Matematis Siswa SMP. KALAMATIKA Jurnal Pendidikan Matematika, 3(2), 155-174.

Penyerahan Naskah: 7 Januari 2018 || Revisi: 26 Juni 2018 || Diterima: 26 Juni 2018

\section{PENDAHULUAN}

Matematika merupakan salah satu bidang ilmu yang memiliki andil dalam mengambangkan daya pikir manusia serta mendukung berkembangnya sains dan teknologi. Oleh karena itu, bidang ilmu tersebut harus dapat dikuasai oleh siswa, baik di sekolah dasar, sekolah menengah pertama dan sekolah menengah atas hingga perguruan tinggi. Kurikulum 2013 menekankan kompetensi yang harus dimiliki siswa dalam pembelajaran matematika diantaranya mencakup ranah sikap, keterampilan kognitif, keterampilan psikomotorik, dan pengetahuan untuk suatu satuan pendidikan. Berdasarkan tingkat pemahaman matematika dari Kinach (2002), salah satu kompetensi matematika dari ranah kognitif yaitu pemahaman matematika. Aspek pemahaman merupakan salah satu dari lima kecakapan matematis, diantaranya pemahaman konseptual, kompetensi strategis matematis, kelancaran prosedur pengerjaan, penalaran adaptif, dan disposisi yang produktif (Kilpatrick, Swafford \& Findell, 2001).

Menurut Depdiknas, tujuan pembelajaran matematika dari SD sampai dengan SMA atau sederajat diantaranya; (1) Siswa dapat memahami konsep matematika, menjelaskan keterkaitan antar konsep dan mengaplikasikan konsep atau algoritma secara luwes, akurat, efisien dan tepat dalam pemecahan masalah; (2) Menggunakan penalaran pada pola dan sikap, memanipulasi matematika dalam membuat generalisasi; (3) Memecahkan masalah yang meliputi kemampuan memahami masalah, merancang model matematika, menyelesaikan 
model dan menafsirkan solusi yang diperoleh; (4) Mengomunikasikan gagasan dengan simbol, tabel, diagram atau media lain untuk memperjelas keadaan atau masalah; (5) Memiliki sikap positif (disposisi) terhadap kegunaan matematika dalam kehidupan, misalnya rasa ingin tahu, perhatian, dan minat mempelajari matematika, serta sikap ulet dan percaya diri dalam pemecahan masalah (Hamzah \& Muhlisrarini, 2014).

Berdasarkan tujuan pembelajaran matematika di atas, bahwa kemampuan pemahaman konseptual matematis merupakan bagian penting yang harus dikuasai siswa. Siswa dengan kemampuan pemahaman konseptual matematis akan terbiasa menyelesaikan permasalahan dengan berbagai cara, karena siswa tersebut memiliki pemahaman yang kuat dan skema yang lengkap terkait dengan materi prasyarat yang harus dikuasai (Kinard \& Kozulin, 2008). Pemahaman konseptual merupakan bekal siswa dalam memecahkan masalah matematika dan menemukan konsep lain (Kilpatrick, Swafford, \& Findel, 2001). Dengan demikian, kemampuan pemahaman koseptual siswa harus dapat tertanam dengan kuat dan baik agar mempermudah dalam menghadapi soal dengan pemecahan masalah yang membutuhkan konsep dasar.

Siswa membutuhkan guru matematika yang kompeten agar dapat berupaya optimal dalam mencapai kompetensi sesuai dengan tuntutan kurikulum. Peran guru dan model pembelajaran dapat membantu mengatasi permasalahan tersebut. Guru dengan berbagai kompetensi yang dimilikinya dapat memilih dan mengembangkan model pembelajaran serta menciptakan suasana pembelajaran di dalam kelas yang dapat melatih dan mendukung kemampuan konseptual matematis.

Salah satu model pembelajaran yang dapat melatih aspek-aspek kemampuan pemahaman konseptual matematis serta tetap mengarah kepada tuntutan kurikulum adalah model pembelajaran dengan berlandaskan kontruktivisme. Landasan berpikir akan pengetahuan yang dibangun sedikit demi sedikit, yang hasilnya diperluas melalui konteks yang terbatas dan tidak dengan tiba-tiba. Manusia harus mengkontruksi pengetahuan dan memberi makna melalui pengalaman nyata karena pengetahuan bukan seperangkat fakta-fakta, konsep atau kaidah yang siap untuk diambil dan diingat. Siswa perlu dibiasakan untuk memecahkan masalah, menemukan sesuatu yang berguna bagi dirinya, dan bergelut dengan ide-ide, yaitu siswa harus mengkontruksikan pengetahuan di benak mereka sendiri (Sagala, 2010). Model pembelajaran yang dikembangkan oleh Knisley (2003), yaitu model 
pembelajaran matematika Knisley merupakan salah satu pembelajaran yang menggunakan landasan berfikir kontruktivisme. Model pembelajaran ini terdiri dari empat tahap (Knisley, 2003) diantaranya allegorisasi, integrasi, analisis dan integrasi. Keempat tahap tersebut membantu siswa dalam membangun pemahamannya sendiri, karena proses pembelajaran diarahkan untuk dapat mengaktifkan pebelajar dalam membangun sikap, keterampilan dan pengetahuannya melalui pengalaman secara langsung.

Berdasarkan tahapan pembelajaran tersebut, model pembelajaran matematika Knisley (MPMK) diduga dapat dijadikan alternatif guru dalam menyajikan pembelajaran yang dapat membantu meningkatkan kemampuan pemahaman konseptual matematis siswa. Oleh karena itu, peneliti mengangkat suatu penelitian untuk menyelidiki dan mendeskripsikan secara komprehensif tentang peningkatan dan pencapaian kemampuan pemahaman konseptual matematis.

Pemahaman merupakan salah satu daerah kognitif dan taksonomi Bloom menyatakan bahwa tujuan pendidikan di ranah kognitif terbagi menjadi enam, salah satunya yaitu aspek pemahaman (Arikunto, 2012). Sudijono (2005) menyatakan bahwa pemahaman adalah kemampuan seseorang untuk mengerti atau memahami sesuatu setelah sesuatu itu diketahui dan diingat. Lebih lanjut ia mengungkapkan bahwa seorang peserta didik dikatakan memahami sesuatu apabila ia dapat memberikan penjelasan atau memberi uraian lebih rinci tentang hal itu dengan menggunakan kata-katanya sendiri. Kesanggupan memahami setingkat lebih tinggi daripada pengetahuan (Sudjana, 2009). Skemp membedakan pemahaman matematika dalam dua jenis yaitu pemahaman relasional dan pemahaman instrumental. Sedangkan Hibert \& Carpenter, mengklasifikasikan pemahaman matematika secara dikhotomi antara pemahaman konseptual dan pemahaman prosedural (Dedy, Mulyana \& Sudihartinih, 2012). Konsep itu sendiri diartikan sebagai ide abstrak yang dapat digunakan untuk menggolongkan sekumpulan objek (Depdiknas, 2003).

Berbagai kerangka berpikir mengenai pemahaman konseptual matematika, Bloom (Suherman, 2003) mengemukakan, bahwa yang dimaksud dengan pemahaman konseptual adalah kemampuan menangkap pengertian-pengertian seperti mengungkapkan suatu materi yang disajikan ke dalam bentuk yang dapat dipahami, mampu memberikan interpretasi dan mampu mengaplikasikanya. Kinach (2002) memodifikasi tingkat pemahaman dari Perkins dan Simmons untuk bidang matematika menjadi enam level pemahaman dengan menguraikan 
content frame menjadi dua tahap pemahaman yaitu content-level understanding (tahap pemahaman konten) dan concept level understanding (tahap pemahaman konsep). Tahap pemahaman konten terkait dengan kemampuan memberikan contoh-contoh yang benar tentang kosa kata (istilah dan notasi), mengingat fakta-fakta dasar, dan terampil menggunakan algoritma atau mereplikasi strategi berpikir dalam situasi tertentu yang telah diajarkan sebelumnya. Pengetahuan pada tahap ini adalah pengetahuan yang diterima siswa, diberikan kepada mereka dalam bentuk informasi atau keterampilan yang terisolasi, bukan diperoleh siswa secara aktif. Pemahaman seperti itu merupakan pemahaman matematika yang paling dangkal.

Tingkat pemahaman konsep setingkat lebih tinggi dari pemahaman konten, dimana siswa terlibat aktif mengidentifikasi, menganalisis dan mensintesis pola-pola serta saling keterkaitan dalam memperoleh pengetahuan. Ciri-ciri dari tingkat pemahaman ini adalah kemampuan mengidentifikasi pola, menyusun definisi, mengaitkan konsep yang satu dengan yang lain. Pemahaman konseptual matematis dapat dilihat dari bagaimana siswa memahami konsep yang diberikan, lalu mengoperasikannya dengan menggunakan operasi-operasi matematika hingga mengaitkannya dengan konsep lain (Kilpatrick, Swafford \& Findell, 2001). Ketiga indikator kemampuan pemahaman konseptual matematis memiliki kaitan. Komponen pemahaman konsep berpengaruh langsung pada komponen pengoperasian dan perelasian konsep. Komponen pengoperasian konsep berpengaruh langsung dengan perelasian konsep. Merujuk dengan hal tersebut, indikator yang digunakan dalam penelitian ini yaitu memahami, mengoperasikan dan mengaitkan konsep.

Model pembelajaran matematika Knisley adalah model pembelajaran yang dikembangkan Jeff Knisley atas dasar teori belajar Kolb Learning Style (KLS) yang berpendapat bahwa gaya belajar siswa dalam memahami pengalaman: pengalaman konkret dan konseptualisasi abstrak, serta dua pendekatan dalam mengubah pengalaman. Selain itu, pada setiap individu memiliki kecenderungan dalam belajar yang dijelaskan dalam learnig cycle atau lingkaran pembelajaran. Gaya belajar David Kolb memuat empat kuadran kecenderungan seseorang dalam proses belajar (Ghufron \& Risnawati, 2014) yaitu:

1. Kuadran perasaan/ pengalaman konkret (concrete experience) yaitu dimana individu belajar melalui perasaan, dengan menekankan segi-segi pengalaman konkrit, lebih 
mementingkan relasi dengan sesama dan sensitivitas terhadap perasaan orang lain. Dalam proses belajar, individu cenderung lebih terbuka dan mampu beradaptasi terhadap perubahan yang dihadapi.

2. Kuadran pengamatan/ refleksi pengamatan (reflection observation) yaitu dimana individu belajar melalui pengamatan, penekanannya mengamati sebelum menilai, menyimak suatu perkara dari berbagai perspektif, dan selalu menyimak hal-hal yang diamati. Dalam proses belajar, individu akan menggunakan pikiran dan perasaannya untuk membentuk opini atau pendapat.

3. Kuadran pemikiran/konseptualisasi abstrak (abstact conceptualization) yaitu individu belajar melalui pemikiran dan lebih terfokus pada analisis logis dari ide-ide, merencanakan secara sistematis dan pemahaman intelektual dari situasi atau perkara yang dihadapi. Dalam proses belajar, individu akan mengandalkan perencanaan sistematis serta mengembangkan teori dan ide untuk menyelesaikan masalah yang dihadapinya.

4. Kuadran tindakan/ eksperimen aktif (active experimentation) yaitu dimana individu belajar melalui tindakan, cenderung kuat dalam segi kemampuan melaksanakan tugas, dan berani mengambil resiko. Dalam proses belajar, individu akan menghargai keberhasilannya dalam menyelesaikan pekerjaan, pengaruhnya pada orang lain dan prestasinya.

Korespondensi atau bisa dikatakan hubungan antara gaya belajar Kolb dan aktivitas pebelajar menurut interpretasinya dalam konteks matematika (Knisley, 2003) diantaranya gaya belajar kongkrit-reflektif berkorespondensi dengan aktivitas pebelajar sebagai allegorizer, gaya belajar kongkrit-aktif berkorespondensi dengan aktivitas pebelajar sebagai integrator, gaya belajar abstrak-reflektif berkorespondensi dengan aktivitas pebelajar sebagai analiser, dan gaya belajar abstrak-aktif berkorespondensi dengan aktivitas pebelajar sebagai sinteser. Sehingga pada tiap-tiap tahapan pembelajaran, guru memiliki peran yang berbedabeda. Ketika siswa melakukan konkrit-reflektif, guru bertindak sebagai storyteller (pencerita). Ketika siswa melaksanakan konkrit-aktif, guru bertindak sebagai pembimbing dan motivator. Ketika siswa sedang melakukan abstrak-reflektif, guru berperan sebagai nara sumber dengan menjustifikasi tentang konsep-konsep baru melalui penjelasan yang masuk akal agar mendapat 
suatu kesimpulan yang logis. Dan ketika siswa melakukan abstrak-aktif, guru berperan sebagai $\operatorname{coach}$ (pelatih).

Pada prosesnya, model pembelajaran Knisley (MPMK) memiliki empat tahap yang dijabarkan dalam beberapa langkah pembelajaran. Tahap dan langkah pembelajaran Knisley mengarahkan siswa dalam membangun pemahamannya secara mandiri. Empat tahapan model pembelajaran matematika Knisley sebagai berikut.

1. Pada tahap allegorisasi, siswa dituntun untuk dapat merumuskan konsep baru secara figuratif dikaitkan dengan konsep-konsep yang telah diketahui dengan baik. Pada tahap ini, siswa belum dapat membedakan konsep baru dengan konsep lama yang telah dikuasai.

2. Pada tahap integrasi, Siswa merealisasikan suatu konsep sebagai sesuatu yang baru, dianggap belum mengetahui bagaimana menghubungkan dengan apa yang telah diketahuinya. Lalu melakukan perbandingan, pengukuran dan eksplorasi untuk membedakan konsep baru yang telah diketahui. Selanjunya siswa diberi tugas yang bersifat mengeksplorasi karakteristik dari konsep baru, sehingga siswa dapat dengan baik mengaitkan hubungan konsep baru dengan konsep lama.

3. Pada tahap analisis, aiswa menghubungkan konsep baru dengan konsep yang telah diketahuinya, tetapi mereka kekurangan informasi yang diperlukan untuk membuat ciri yang khas (unik) dari konsep itu. Sehingga siswa perlu membuat atau memilih pernyataan yang terkait dengan konsep baru, memberi contoh kontra untuk menyangkal pernyataan yang salah dan membuktikan pernyataan yang benar bersama-sama dengan guru. Pada tahap ini konsep baru menjadi bagian dari pengetahuan yang telah ada.

4. Pada tahap sintesis, Siswa melakukan latiha setelah menguasai konsep dan dapat menggunakannya untuk memecahkan masalah, mengembangkan strategi, dan menciptakan allegoris karena konsep baru dengan ciri khas yang unik telah menjadi alat dalam mengembangkan strategi dalam melakukan allegorisasi kembali.

Tahap sintesis meliputi penguasaan topik, konsep baru menjadi suatu alat. Siswa dapat menggunakannya untuk mengembangkan strategi individu untuk memecahkan masalah. Model pembelajaran ini membentuk siklus di setiap tahapnya. Siklus dari model pembelajaran matematika Knisley (MPMK) sebagaimana gambar 1. 


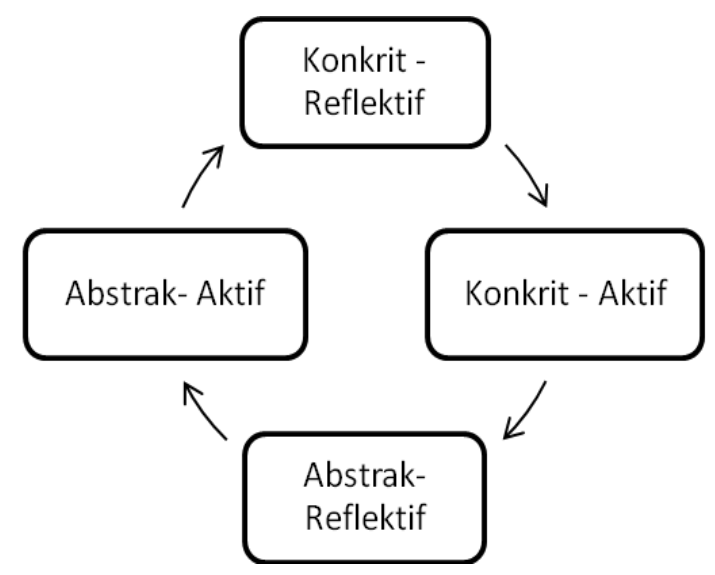

Gambar 1. Siklus pembelajaran MPMK

\section{METODE PENELITIAN}

Metode penelitian yang digunakan dalam penelitian ini adalah metode kombinasi (mixed method) karena data pencapaian dan peningkatan akan digambarkan secara terperinci, komprehensif dan mendalam dengan didukung data kualitatif. Desain Penelitian yang digunakan adalah concurrent embedded design dengan model penggabungan KUAN-kual (Sugiyono, 2013). Dalam model penggabungan ini, kuantitatif sebagai data primer dan kualitatif sebagai data sekunder. Metode tersebut digunakan secara bersama-sama dan dalam waktu yang sama, tetapi independen untuk menjawab rumusan masalah sejenis. Data kualitatif diperoleh untuk memperkuat hasil analisis data kuantitatif.

Populasi dalam penelitian ini adalah seluruh siswa kelas VIII SMP Negeri 6 Kota Serang tahun ajaran 2015/2016. Populasi adalah keseluruhan objek atau subjek penelitian. Kelas yang digunakan dalam sampel ini sebanyak dua kelas dari kelas VIII yaitu kelas VIII A dan B. Kelas A dengan banyak siswa 37 orang dan kelas B dengan banyak siswa 36 orang.

Pokok bahasan matematika yang diteliti dalam penelitian ini yaitu persamaan linear dua variabel (SPLDV). Instrumen tes berupa tes dan non tes. Instrumen tes kemampuan pemahaman konseptual matematis berupa tes uraian sebelum (pretes) dan setelah (postes) perlakuan. Adapun instrumen non tes berupa lembar observasi, pedoman wawancara, dokumen berupa hasil pekerjaan siswa, hasil wawancara, dokumentasi berupa foto dan peneliti sebagai intrumen penelitian utama.

Data kuantitatif dianalisis dengan statistik dan data kualitatif dianalisis secara kualitatif. Dalam menganalisis data kuantitatif dilakukan langkah analisis dengan menggunakan statistik deskriptif dan statistik inferensial. Adapun analisis data kualitatif 
menggunakan teknik tiga jalur analisis yaitu reduksi, penyajian dan penarikan kesimpulan. Dokumentasi jawaban siswa merupakan bahan wawancara dan observasi yang kemudian hasil wawancara dan observasi yang disajikan dalam narasi dan disederhanakan dengan memilih catatan yang dianggap perlu digali.Selanjutnya kesimpulan data diverifikasi selama penelitian berlangsung. Dengan cara memikir ulang selama penulisan, tinjauan ulang catatan lapangan, tinjauan kembali dan tukar pikiran antar teman sejawat.

Langkah prosedur penelitian yang digunakan dengan tahapan diantaranya studi lapangan untuk mengetahui karakteristik sampel penelitian, perijinan pelaksanaan penelitian, penyusunan instrumen dan perangkat pembelajaran, uji coba instrumen, analisis data hasil uji coba dan revisi, pretes, pelaksanaan pembelajaran, postes, penarikan kesimpulan dan pelaporan.

\section{HASIL DAN PEMBAHASAN}

Berikut ini uraian hasil penelitian yang telah dilakukan serta pembahasannya. Data kemampuan pemampuan pemahaman konseptual matematis diperoleh melalui pretes, postes, dan $N$-gain. Berikut ini merupakan deskripsi pretes, postes, dan $N$-gain pada kelas eksperimen dan kelas kontrol.

Tabel 1. Hasil Analisis Statistika Deskriptif Tes Kemampuan Pemahaman Konseptual Matematis

\begin{tabular}{llccccc}
\hline \multirow{2}{*}{ Nilai } & $\mathrm{N}$ & Eksperimen & \multicolumn{3}{c}{ Kontrol } \\
& 36 & $\mathrm{SD}$ & $\mathrm{N}$ & $\bar{x}$ & $\mathrm{SD}$ \\
\hline Pretes & 36 & 0,83 & 14,08 & 37 & 0,89 & 1,07 \\
Postes & 36 & 3,98 & 37 & 10,27 & 4,19 \\
$N$-gain & 36 & 0,58 & 0,163 & 37 & 0,39 & 0,167 \\
\hline
\end{tabular}

Untuk lebih jelasnya gambaran dari Tabel 1, perbandingan rataan skor pretes dan postes dapat dilihat pada gambar 2 sebagai berikut.

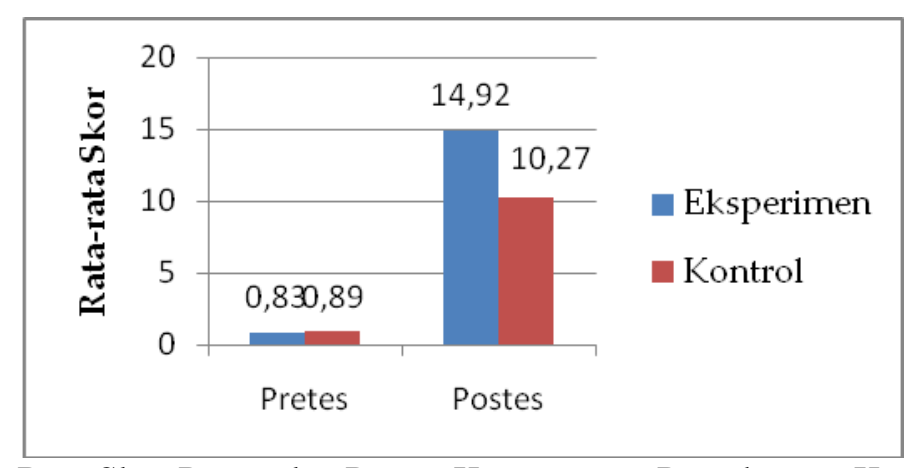

Gambar 2. Nilai Rata-Rata Skor Pretes dan Postes Kemampuan Pemahaman Konseptual Matematis 
Berdasarkan gambar 2, tampak bahwa selisih skor pretes kelas eksperimen dan kontrol sebesar 0,06 dapat dikatakan rata-rata pretes kedua kelas sama. Sedangkan, rata-rata postes kelas eksperimen yang mendapatkan model pembelajaran matematika Knisley lebih baik dengan pencapaian 14,92 dibandingkan kelas kontrol yang mendapatkan pembelajaran langsung mencapai 10,27. Berdasarkan data tersebut, menunjukkan bahwa terjadi peningkatan skor kemampuan pemahaman konseptual matematis setelah pembelajaran dilaksanakan.

Analisis data secara statistika inferensial dengan kriteria pengujian : jika nilai sig < 0,05, maka $H_{O}$ ditolak; dan jika nilai sig $\geq 0,05$, maka $H_{O}$ diterima. Pada taraf signifikansi $\alpha=$ 0,05 diperoleh hasil analisis seperti pada Tabel 2 .

Tabel 2. Hasil Uji Perbedaan Rata-Rata Skor Kemampuan Pemahaman Konseptual Matematis

\begin{tabular}{ccccc}
\hline Data & Statistik & Nilai Sig & Keterangan & Kesimpulan \\
\hline Pretes & $\begin{array}{c}\text { Mann-Whitney U } \\
\text { Asymp. Sig. (2-tailed) }\end{array}$ & 0,827 & $H_{\text {O diterima }}$ & Kemampuan awal sama \\
N-Gain & $\begin{array}{c}\text { Independent-Sampels T Test } \\
\text { Asymp. Sig. (1-tailed) } \\
\text { Independent-Sampels T Test } \\
\text { Asymp. Sig. (1-tailed) }\end{array}$ & 0,000 & $H_{\text {Oditolak }}$ & Hipotesis diterima \\
\hline
\end{tabular}

Berdasarkan hasil uji pada tabel 2, menunjukkan $H_{0}$ ditolak artinya peningkatan kemampuan pemahaman konseptual matematis kelas eksperimen yang mendapatkan pembelajaran dengan model pembelajaran matematika Knisley lebih baik daripada siswa kelas kontrol yang mendapatkan model pembelajaran langsung. Hasil tersebut memberikan gambaran bahwa model pembelajaran matematika Knisley dapat mengembangkan kemampuan pemahaman konseptual matematis. Hal ini terjadi karena dalam pembelajaran, siswa diberikan kesempatan untuk merumuskan untuk dapat merumuskan (mengaitkan) konsep yang akan dipelajari secara figuratif pada lembar aktivitas siswa (LAS) yang telah dibuat oleh guru. Pada LAS yang dibuat memuat pertanyaan yang memicu siswa berpikir kritis, serta kolom jawaban sebagai tempat siswa merumuskan konsep materi baru secara mandiri. Konsep yang sebelumnya menjadi allegoris (lambang) untuk merumuskan konsep baru. Siswa didorong untuk dapat mengaitkan konsep yang telah didapat untuk merumuskan konsep baru. Hal ini mendorong siswa untuk berpikir kritis dan aktif berdiskusi antar teman dan mencari sumbersumber bacaan yang lengkap.

Dalam memperoleh data sebagai fakta pendukung sehingga memperkuat data kuantitatif berikut akan disajikan hasil analisis secara kualitatif yang diambil dari dokumentasi 
hasil pekerjaan siswa, hasil observasi dan wawancara. Hasil analisis jawaban tes KPKM pada siswa yang termasuk kategori tinggi pada soal no 4.

Suatu persegi panjang memiliki keliling $28 \mathrm{~cm}$. lebarnya kurang $2 \mathrm{~cm}$ dari panjangnya. Berapa luas daerah persegi panjang tersebut?
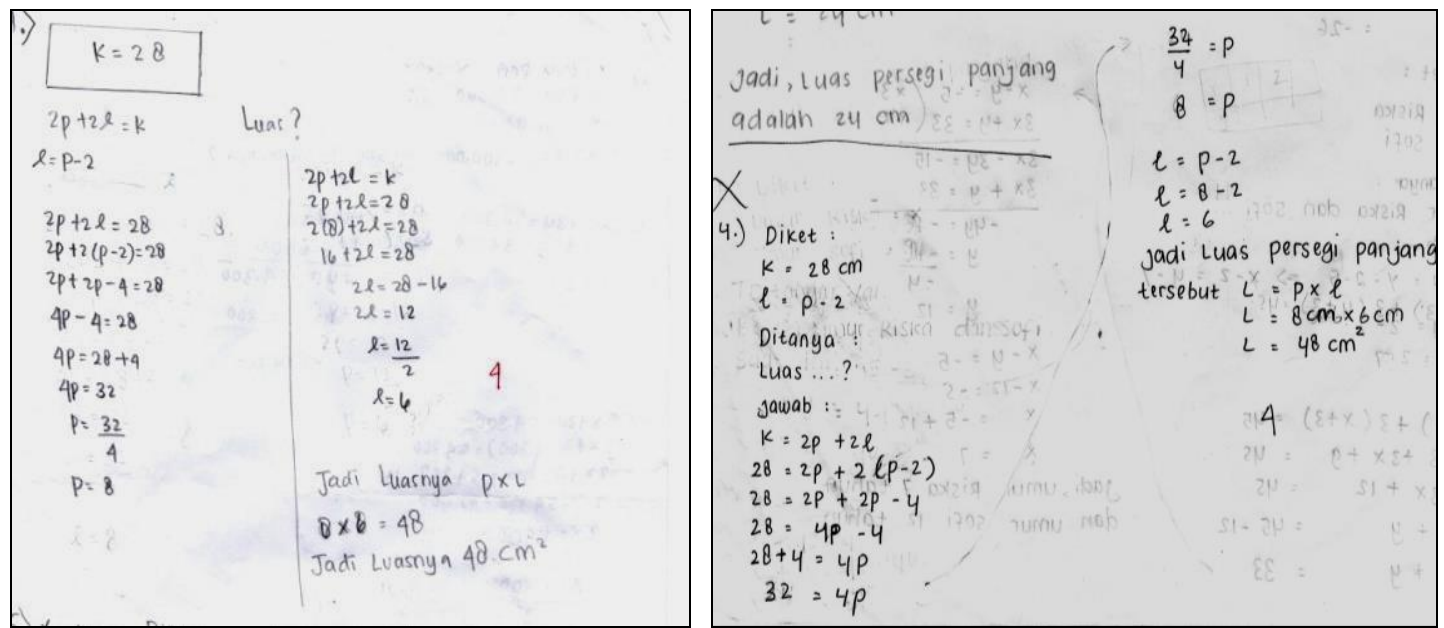

Gambar 3. Jawaban Siswa Kelas Eksperimen Kategori Tinggi

Berdasarkan gambar 3, siswa kelas eksperimen mampu mengaitkan konsep keliling persegi panjang dengan konsep sistem persamaan linear dua variabel. Langkah penyelesaian yang diambil dengan menggunakan teknik subtitusi karena menggunakan informasi langsung yang ada di dalam soal. Namun siswa kategori tinggi di kelas kontrol dalam menyelesaikan butir soal ini melakukan kesalahan dalam menginterpretasikan soal yang diberikan. Sehingga siswa belum tepat dalam menjawab pada pertanyaan ini. Berikut ini salah satu hasil jawaban siswa kategori tinggi pada kelas kontrol.
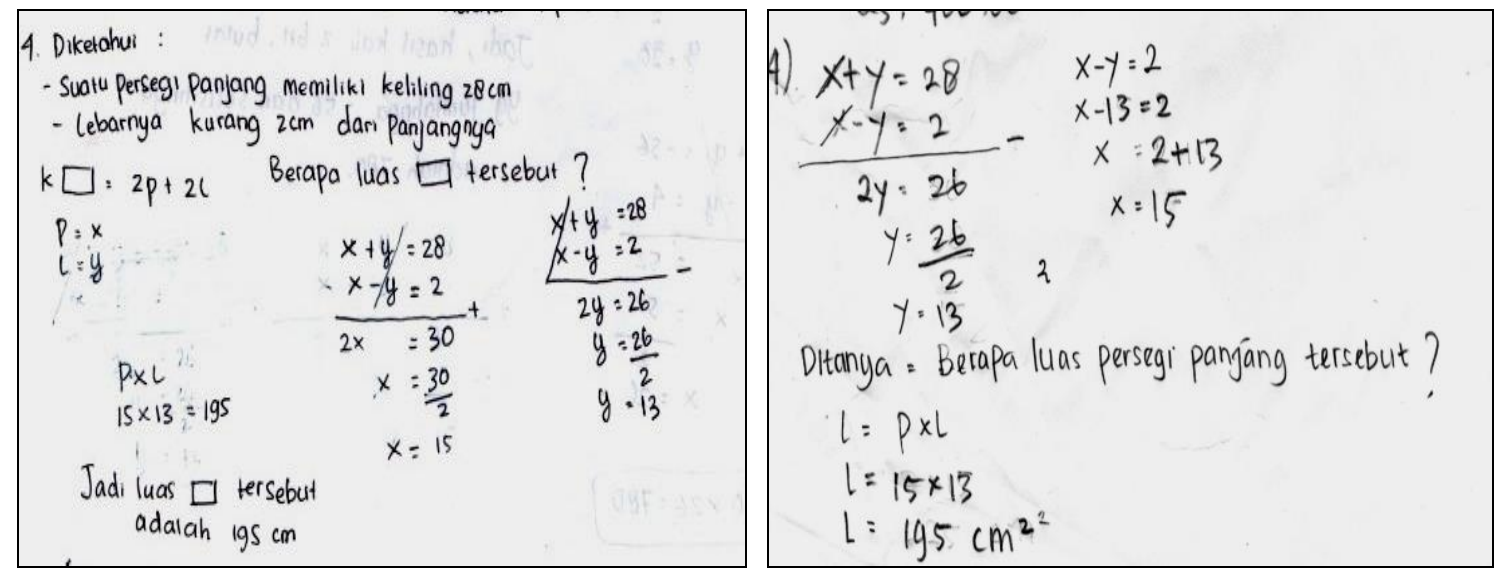

Gambar 4. Jawaban Siswa Kelas Kontrol Kategori Tinggi 
Berdasarkan gambar 4, siswa kelas kontrol dapat mencari nilai variabel dengan menggunakan langkah eliminasi. Namun, dalam mengaitkan konsep keliling persegi panjang dengan konsep sistem persamaan linear dua varibel masih belum tepat sesuai rumus keliling persegi panjang, sehingga hasil akhir yang diperoleh pun salah. Setelah diwawancara ternyata siswa mengakui bahwa masih merasa sulit untuk mengungkapkan keliling persegi panjang ke dalam konsep SPLDV dan menyatakan keterangan dari soal "lebarnya kurang $2 \mathrm{~cm}$ dari panjangya" sehingga dapat dipastikan bahwa siswa masih belum sepenuhnya dapat mengaitkan konsep di luar konsep SPLDV dengan konsep SPLDV khususnya dalam mengungkapkan model matematika dengan persamaan aljabar.

Selanjutnya untuk soal KPKM no 5,

Dua tahun yang lalu, umur Riska lima tahun lebih muda dari pada umur Sofi. Tiga tahun yang akan datang, umur Sofi ditambah tiga kali umur Riska adalah 45 tahun. Tentukan umur Riska dan umur Sofi saat ini.
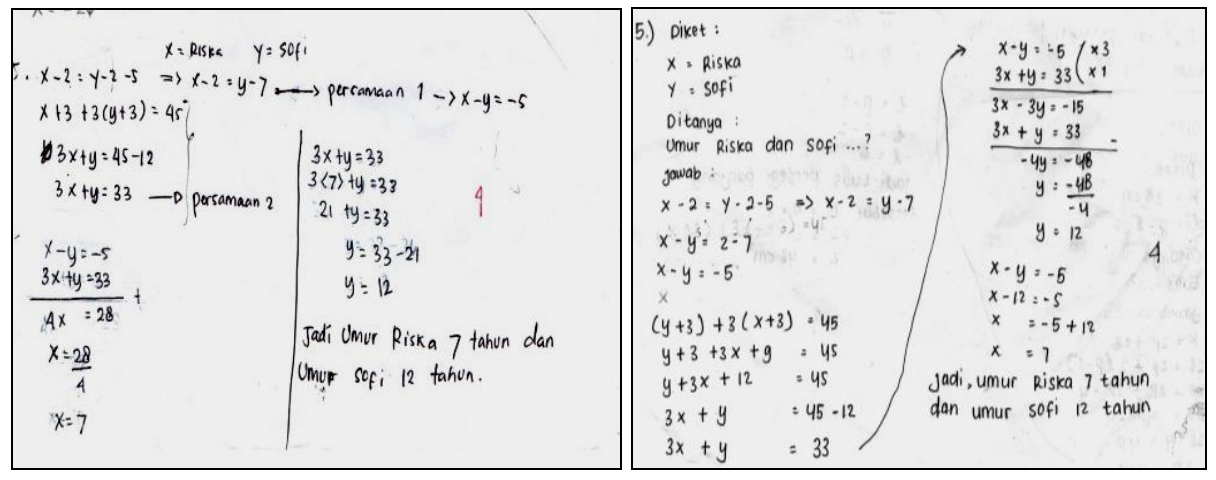

Gambar 5. Jawaban Siswa Kelas Eksperimen Kategori Tinggi

Dari gambar 5, hasil jawaban siswa kelas eksperimen pada kategori tinggi mampu menyusun model matematika dengan konsep sistem persamaan linear dua variabel yang dikaitkan dengan umur manusia dan menyelesaikannya dengan tepat dan lengkap. Berdasarkan hasil wawancara, siswa merasa tidak mudah untuk menyusun model tersebut karena keterangannya yang cukup rumit untuk dapat menyimpulkan dari awal keterangan yang diketahui hingga hasil akhir dengan benar. Untuk membandingkan hasil jawaban siswa kelas kontrol, disajikan pada gambar 6. 

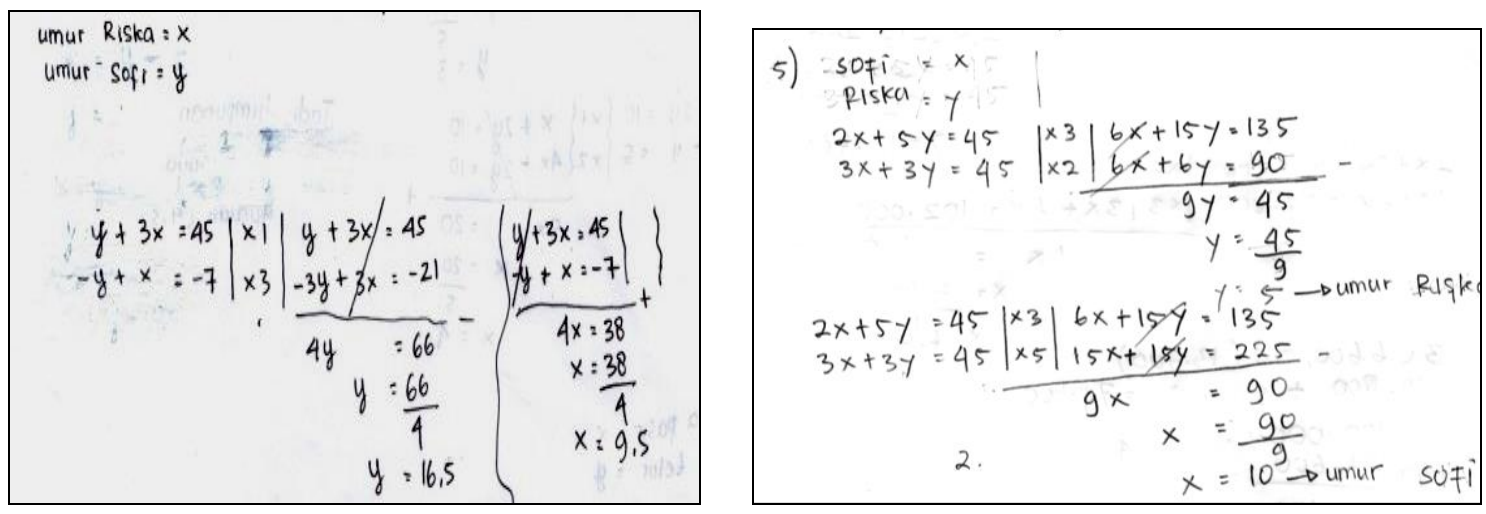

Gambar 6. Jawaban Siswa Kelas Kontrol Kategori Tinggi

Hasil analisis butir soal no 5, kedua subjek belum dapat membuat model matematika dengan lengkap Subjek dari kelas kontrol membuat model matematika $(y+3 x=45)$, model matematika tersebut hampir mendekati benar namun keterangan dari soal yang menyatakan "tiga tahun yang akan datang" tidak diikutsertakan sehingga menjadi $((y+3)+3(x+3))$. Model matematika yang dibuat, setiap keterangan waktu "dua tahun yang lalu dan tiga tahun yang akan datang" dijadikan koefisien dalam persamaan variabel $x$ dan $y$ yang seharusnya dijumlahkan dengan variabelnya. Sehingga dapat dilihat bahwa siswa kategori tinggi di kelas kontrol masih membutuhkan banyak latihan dalam bentuk soal SPLDV yang non rutin.

Dalam penelitian ini, ditemukan untuk siswa yang termasuk kategori rendah baik di kelas maupun kelas kontrol banyak ditemukan siswa lemah dalam memahami konsep sistem persamaan linear dua variabel dan operasi pada aljabar secara lengkap sehingga jawaban yang diberikan tidak tuntas. Berikut ini akan disajikan salah satu hasil jawaban siswa dengan instrumen penelitian pada butir soal no 1, sebagai berikut.

Diketahui sistem persamaan $12 x+21 y=27$ dan $21 x+12 y=72$. Tentukan nilai $9 x+7 y$ ?

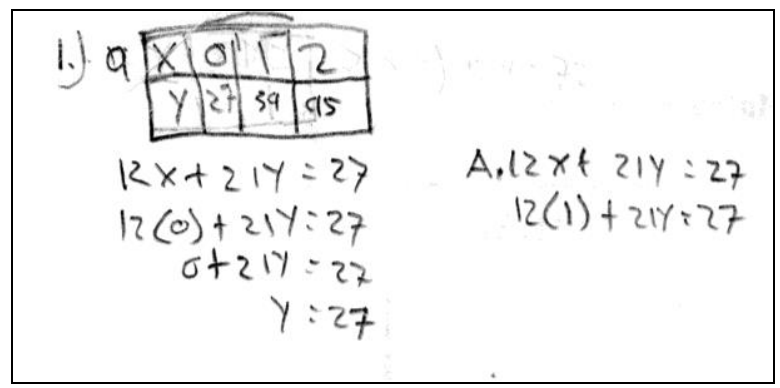

Gambar 7. Jawaban Siswa Kategori Rendah Kelas Eksperimen

Dapat dilihat dari hasil jawaban siswa pada gambar 7, siswa mencoba menyelesaikan dengan metode grafik namun tidak tuntas dan salah dalam perhitungan aljabar. Setelah diwawancara 
lebih dalam, diakui bahwa siswa tersebut belum menguasai operasi aljabar dengan baik sehingga menghambat proses menyelesaikan soal.

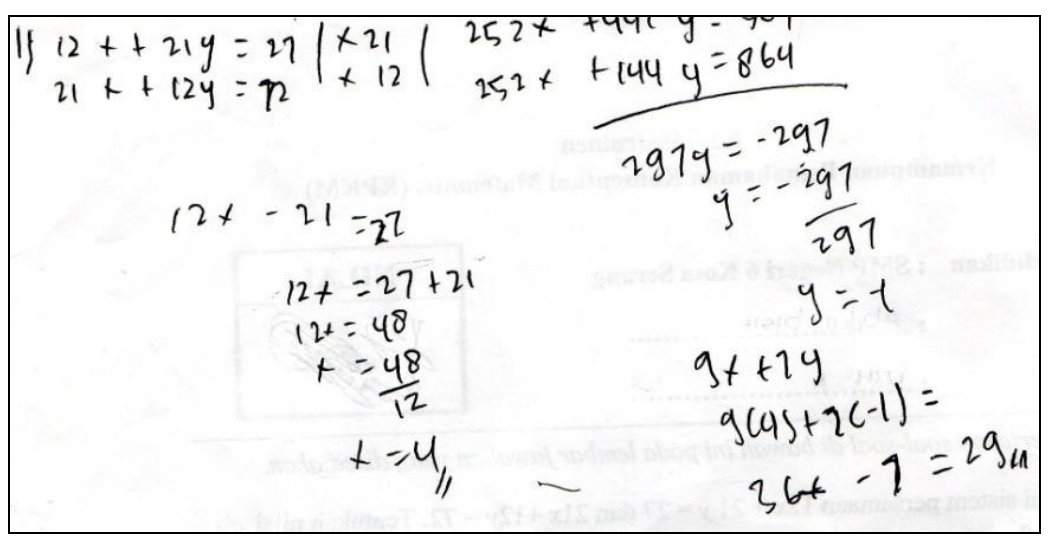

Gambar 8. Jawaban Siswa Kategori Rendah Kelas Kontrol

Berdasarkan jawaban siswa kategori rendah kelas kontrol pada gambar 8, siswa dapat menyelesaikan dengan benar. Namun, setelah diwawancarai lebih mendalam dan diuji oleh beberapa operasi aljabar, siswa masih lemah dalam mengoperasikan konsep aljabar. Soal selanjutnya akan disajikan jawaban siswa pada butir soal 2, sebagai berikut.

Dari SPLDV berikut:

$x+2 y=10$

$2 x-y=5$

Tentukanlah himpunan penyelesaiannya!

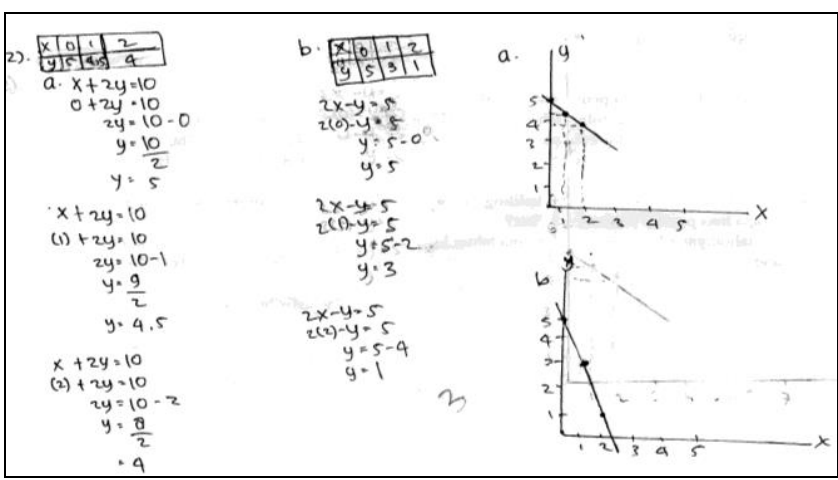

Gambar 9. Jawaban Siswa Kategori Rendah Kelas Eksperimen 


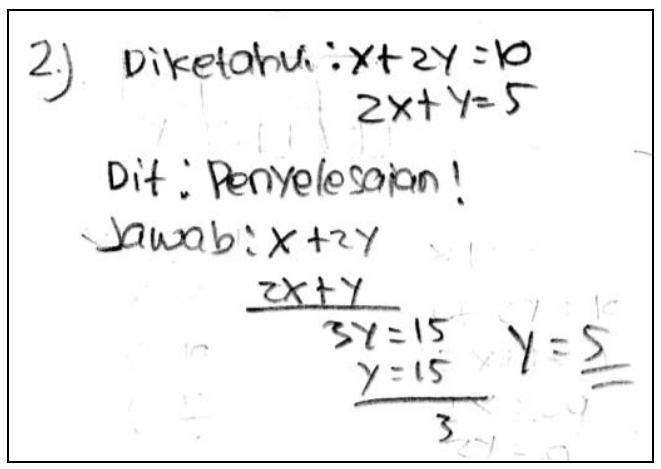

Gambar 10. Jawaban Siswa Kategori Rendah Kelas Kontrol

Berdasarkan jawaban siswa no 2 pada gambar 9, siswa kelas eksperimen salah mengartikan soal SPLDV dengan metode grafik karena dapat dilihat antara grafik PLDV satu dengan yang lainnya tidak membentuk sistem. Sedangkan pada gambar 10 jawaban siswa pada kelas kontrol, berusaha menyelesaikan operasi dengan eliminasi namun belum tepat dalam mengoperasikannya. Dalam proses eliminasi, siswa tidak menyamakan koefisien variabel yang ingin dieliminasi sehingga tidak ditemukan jawaban akhir dengan benar. Sehingga dapat ditemukan pada siswa kategori rendah di kedua kelas masih ditemukan siswa yang belum menguasai dan memahami konsep SPLDV. Hal ini karena keterbatasan dan lemahnya penguasaan materi prasyarat berupa operasi pada aljabar dan bilangan bulat. Hal ini seperti yang dinyatakan Rosnawati (2013), materi prasyarat mengenai operasi bilangan masih kurang mendapatkan perhatian, karena materi operasi bilangan yang rendah menyebabkan anak Indonesia dalam menyelesaikan soal TIMSS pada masalah yang tidak tergolong sulit mengenai operasi bilangan memperoleh persentase yang masih rendah.

\section{Kesulitan Siswa}

Faktor pertama adalah respon siswa masih merasa belum dapat menyesuaikan dengan pembelajaran yang menuntut siswa berpikir sendiri. Berdasarkan hasil pengamatan dan wawancara, siswa merasa jenuh dan menginginkan penjelasan secara detail dari guru terlebih dahulu seperti pada pembelajaran biasanya sebelum dihadapkan oleh permasalahan dan latihan. Hal ini, senada dengan pendapat Sumarmo, dkk (2012), pembelajaran yang mengutamakan siswa belajar aktif secara mandiri belum sepenuhnya memberi hasil yang memuaskan dalam pencapaian kemampuan matematis. Pembelajaran yang menugaskan siswa belajar sendiri terus menerus dalam waktu yang cukup lama menimbulkan rasa bosan sehingga mengurangi kegairahan dalam belajar. 
Faktor yang kedua adalah lemahnya penguasaan materi prasyarat yang dikuasai siswa. Materi prasyarat ini meliputi operasi bilangan bulat, pecahan dan operasi pada konsep aljabar. Hal ini juga diakui oleh guru mata pelajaran matematika, beberapa siswa masih belum menguasai konsep operasi bilangan sehingga tidak dapat dipungkiri bila saat pembelajaran masih banyak yang membutuhkan bantuan untuk mengulas kembali.

\section{Tinjauan Indikator Kemampuan Pemahaman Konseptial Matematis}

Untuk melihat gambaran hasil tiap indikator kemampuan pemahaman konseptual matematis dapat dilihat pada Gambar 11.

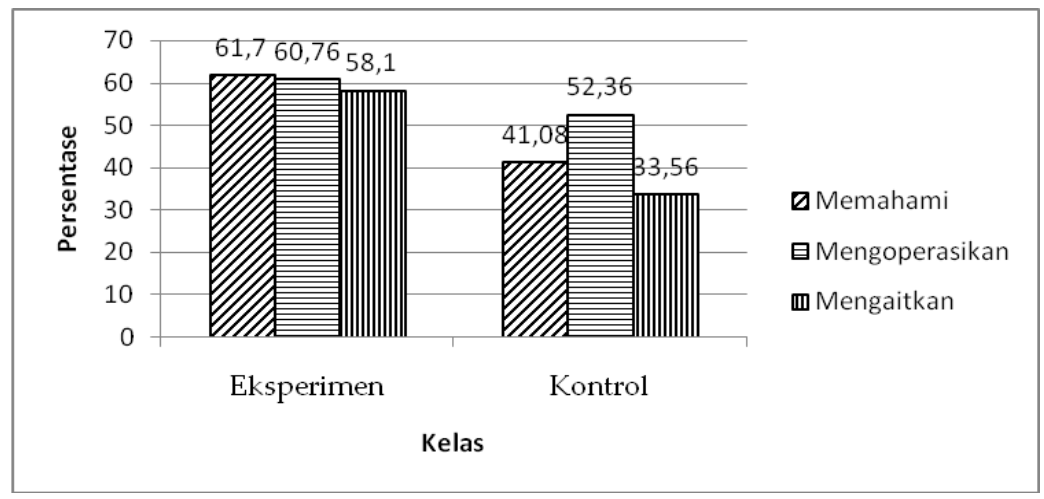

Gambar 11. Analisis Tiap Indikator Kemampuan Pemahaman Konseptual Matematis

\section{Indikator Memahami Konsep}

Untuk soal dengan indikator memahami konsep, siswa menganggap dapat menyelesaikannya dengan baik. Perbedaan pemahaman konsep antara kelas eksperimen dan kontrol tidak jauh berbeda. Siswa di kedua kelas tersebut dapat memahami soal yang dikemas dengan uraian ke dalam bentuk SPLDV.

\section{Indikator Mengoperasikan Konsep}

Persentase dan kategori pencapaian masing-masing kelas pada indikator ini lebih baik dicapai oleh kelas eksperimen daripada kelas kontrol. Hasil ini dipengaruhi secara langsung oleh hasil pencapaian pada indikator memahami konsep karena dalam proses mengoperasikan konsep SPLDV harus dengan pemahaman mengenai konsep SPLDV yang baik. Hal ini sesuai dengan pendapat Hendrayana (2017), pemahaman konsep berpengaruh langsung terhadap pengoperasian konsep. 


\section{Indikator Mengaitkan Konsep}

Kriteria pencapaian pada mengaitkan konsep dipengaruhi oleh pencapaian pada indikator memahami konsep. Hal ini karena dalam merelasikan suatu konsep membutuhkan pemahaman konsep (Kilpatrik, Swaffod \& Findel, 2001). Siswa kelas eksperimen dengan pemahaman konsep yang cukup sehingga dalam mengaitkan konsep pun tidak mencapai lebih dari kriteria cukup, begitu pun pada kelas kontrol yang memperoleh kriteria kurang dalam indikator memahami konsep sehingga dalam mengaitkan konsep dapat dikatakan buruk. Pencapaian ini menggambarkan pencapaian kelas eksperimen lebih baik daripada kelas control. Kesulitan kelas eksperimen dan kontrol dalam mengaitkan konsep yaitu dalam membuat model matematika. Kelas kontrol sudah dapat mengidentifikasi konsep apa yang disajikan di dalam soal, namun kesalahan dilakukan dalam mengaitkan konsep tersebut ke dalam bentuk umum SPLDV. Siswa mengakui soal no 3, 4, dan 5 merupakan soal yang sulit karena konsep SPLDV disajikan dengan dikaitkan konsep lain. Hal ini sesuai dengan hasil penelitian Hendrayana (2017) yang menyebutkan bahwa indikator mengaitkan konsep adalah indikator yang memiliki tingkat kesulitan paling tinggi.

Kendala untuk meningkatkan indikator ini di kelas eksperimen karena siswa kurang berkonsentrasi saat pembelajaran. Hal ini karena siswa belum terbiasa dengan menyelesaikan LAS sebelum dijabarkan secara langsung dan detail mengenai konsep materi oleh guru. Upaya meminimalisir respon siswa yang negatif terhadap LAS yaitu dengan penekanan untuk dapat membaca materi yang akan dipelajari di rumah sebelum materi di pelajari di kelas.

\section{KESIMPULAN}

Berdasarkan rumusan masalah dan hasil penelitian serta pembahasan terhadap hasilhasil penelitian sebagaimana diuraikan sebelumnya diperoleh kesimpulan dari hasil-hasil penelitian adalah pencapaian kemampuan pemahaman konseptual matematis siswa dengan model pembelajaran matematika Knisley lebih baik daripada siswa yang memperoleh pembelajaran langsung. Selain itu, peningkatan kemampuan pemahaman konseptual matematis siswa dengan model pembelajaran matematika Knisley lebih baik daripada siswa yang memperoleh pembelajaran langsung. 


\section{REKOMENDASI}

Berdasarkan kesimpulan penelitian ini, maka dikemukakan beberapa rekomendasi sebagai berikut:

1. Pembelajaran dengan model pembelajaran matematika Knisley hendaknya dapat digunakan sebagai salah satu alternatif model pembelajaran matematika bagi guru untuk meningkatkan kemampuan pemahaman konseptual matematis.

2. Untuk mengoptimalkan proses pembelajaran dengan model pembelajaran matematika Knisley direkomendasikan perlu dapat memperhatikan alokasi waktu yang telah ditetapkan untuk tiap-tiap tahapan pembelajaran dengan baik, sehingga cukup untuk melaksanakan tahap sintesis.

3. Untuk memaksimalkan peningkatan kemampuan pemahaman konseptual matematis yang ingin dicapai dengan model pembelajaran matematika Knisley, siswa perlu memiliki prasyarat kematangan pengetahuan dan penguasaan materi sebelum mengikuti pembelajaran dengan model pembelajaran matematika Knisley. Dengan demikian, sebaiknya siswa diberi tugas rumah untuk belajar di rumah dan mengerjakan soal-soal tentang materi yang akan dipelajari.

4. Kemungkinan adanya kendala-kendala pelaksanaan pembelajaran matematika Knisley pada awal pembelajaran perlu diantisipasi oleh guru. Siswa belum terbiasa belajar mandiri, dan berdiskusi dapat menghambat keberhasilan proses pembelajaran. Oleh karena itu, disarankan guru dapat membantu siswa mengatasi masalah tersebut dan memberikan perhatian lebih kepada siswa yang lemah dalam penguasaan materi prasyarat salah satunya dengan menggunakan teknik scaffolding.

5. Untuk penelitian selanjutnya agar dapat mendapatkan hasil yang akurat dan terpercaya dengan menggunakan observer lebih dari satu. Keterbatasan peneliti dalam memilih dan meminta seseorang untuk dapat bersedia menjadi observer merupakan kekurangan pada penelitian ini.

6. Pada penelitian ini hanya dikaji kemampuan pemahaman konseptual matematis saja, untuk itu direkomendasikan pada penelitian lainnya untuk mengkaji penerapan model pembelajaran matematika Knisley dalam kemampuan matematis lainnya di tingkat SMA atau sederajat. 


\section{REFERENSI}

Arikunto, S. (2012). Dasar-Dasar Evaluasi. Jakarta: Bumi Aksara.

Dedy, E., Mulyana, E., \& Sudihartinih, E. (2012). Pengembangan Bahan Ajar Kalkulus Vektorberdasarkan Model Pembelajaran Matematikaknisley Sebagai Upaya Meningkatkan Kompetensi Matematika Mahasiswa. Pythagoras: Jurnal Pendidikan Matematika, 7(1).

Depdiknas. (2003). Pedoman Khusus Pengembangan Sistem Penilaian Berbasis Kompetensi SMP. Jakarta: Depdiknas.

Ghufron, M. N., \& Risnawita, R. (2014). Gaya Belajar Kajian Teoritik. Yogyakarta: Pustaka Pelajar.

Hamzah \& Muhlisrarini. (2014). Perencanaan Dan Strategi Pembelajaran Matematika. Jakarta: PT Raja Grafido Persada.

Hendrayana, A. (2017). Pengaruh pembelajaran pendekatan rigorous mathematical thinking (RMT) terhadap pemahaman konseptual matematis siswa SMP. Jurnal Riset Pendidikan Matematika, 4(2), 186-199.

Kilpatrik, J., Swafford, J., \& Findell, B. (2001). Adding It Up: Helping Children Learn Mathematics. Washingtong, DC: National Academy Press.

Kinach, B. M. (2002). Understanding and Learning-to-explain by Representing Mathematics: Epistemological Dilemmas Facing Teacher Educators in the Secondary Mathematics“Methods"Course. Journal of Mathematics Teacher Education, 5(2), 153186.

Kinard, J. T., \& Kozulin, A. (2008). Rigorous Mathematical Thinking: Conceptual Formation in The Mathematics Classroom. Cambridge Univ. Press.

Knisley, J. (2003). A Four- Stage Model of Mathematical Learning. Mathematical Educator, 12(1), 10, (Online), (http://WilsonCoe.uga.edu/DEPT/TME/Issue/v12n1/3Knisley). 
Rosnawati, R. (2013). Kemampuan penalaran matematika siswa SMP Indonesia pada TIMSS 2011. In Prosiding Seminar Nasional Penelitian, Pendidikan dan Penerapan MIPA, Fakultas MIPA, Universitas Negeri Yogyakarta (Vol. 18).

Sagala, S. (2010). Konsep dan Makna Pembelajaran. Bandung: CV Alfabeta.

Sudijono, A. (2005). Pengantar Statistik Pendidikan. PT Raja Grafindo Persada.

Sudjana, N. (2009). Dasar-dasar Proses pembelajaran. Bandung: Sinar Baru Algesindo.

Sugiyono. (2013). Metode Penelitian Kombinasi (Mixed Methods). Bandung: CV Alfabeta

Suherman, E. (2003). Strategi Pembelajaran Matematika Kontemporer. Bandung: UPI

Sumarmo, U., Hidayat, W., Zukarnaen, R., Hamidah, M., \& Sariningsih, R. (2012). Kemampuan dan Disposisi Berpikir Logis, Kritis, dan Kreatif Matematik (Eksperimen terhadap Siswa SMA Menggunakan Pembelajaran Berbasis Masalah dan Strategi ThinkTalk-Write). Jurnal Pengajaran MIPA, 17(1), 17-33. 